\title{
Effect of graded levels of teak (Tectona grandis) kernel meal on growth performance and carcass characteristics of rabbit (Oryctolagus cunniculus)
}

Egbewande, O. O., Olorunsanya, A. O. and Adebanjo, T. I.

Department of Animal Production, Faculty of Agriculture, Ibrahim Badamasi Babangida

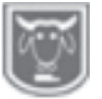

University, Lapai, Niger State.

Corresponding author: femi2015.ooe@gmail.com, $+2348059434531,+2347068233925$

\section{Abstract}

The study was conducted to determine the effects of graded levels of teak (Tectona grandis) kernel meal on rabbits. Thirty weaned rabbits aged between $4-5$ weeks old were which lasted for 12 weeks. The rabbits were randomly allotted to five dietary treatments of two replicates consisting of three rabbits each in a completely randomized design. The calyx layer of the kernel was removed via sieving and rubbing in-between the palms, and the middle layer coupled with the innermost layer were crushed and milled using huller mill to obtain teak kernel meal. Experimental diets were compounded in such a way that Diet 1 contained no teak kernel meal (control) while Diets 2, 3, 4 and 5 contained the test ingredient at 5, 10, 15 and $20 \%$ levels of inclusion respectively. Teak kernel meal was analysed for moisture, crude fibre (CF), crude protein (CP), ether extract (EE), ash and nitrogen free extract (NFE). The results for moisture, crude fibre, crude protein, ether extract, ash and nitrogen free extract were 7.36, 54.90, 8.75, 8.50, 5.00 and 16.88\% respectively. Anti-nutritional factors were also analysed for oxalate, phytate, cyanide, tannin, flavonoid and alkanoid, and the results were $28.6 \mathrm{mg}, 3.65,0.32,2.35,3.12$ and $0.42 \%$ respectively. Rabbits fed Diet 1 had the highest final weight of $1635.88 \mathrm{~g}$ while those fed Diet 5 exhibited the least (1411.20g). There were significant $(P<0.05)$ differences among daily feed intake of the rabbits. The study suggests that rabbits can tolerate $20 \%$ of the test ingredient without any deleterious effect.

Keywords: rabbits, performance, teak kernel meal, proximate analysis, anti-nutrients

\section{Introduction}

The use of conventional feedstuffs in the preparation of livestock feed has put the industry into direct competition with human for the feedstuffs (Muriu et. al., 2002). High costs of conventional sources of energy and protein have been the major reason for the high cost of rabbit feed. The high cost of feed in turn has made livestock production an expensive venture which has caused serious animal protein deficiency among Nigerians, especially inthe low income class, leading to malnutrition (Madubuike and Obidimma, 2009). Rabbit has the potential for filling the gap between demand and supply of animal protein in developing countries like Nigeria. This is because of its high genetic potential, short generation intervals, high fecundity, rapid growth rate, high prolificacy and relative low cost of production (Akinnusi et al., 2007). Rabbits are efficient converters of feed to meat, and can utilize up to $30 \%$ crude fibre as against $10 \%$ by most poultry species (Egbo et al., 2001). With the above great potentials of rabbit, its production is facing the problem of high cost of feed. One of the possible options advocated to solving the present high costs of feedstuffs, according to Olorede and Longe (1999) is the substitution of the conventional feeding stuffs with non-conventional types. With the diversified uses of most of the conventional feedstuffs there is therefore, a necessity for the utilization of underexploited farm produce as feed resources 
Graded levels of teak (Tectona grandis) kernel meal on growth performance and carcass characteristics of rabbit (Oryctolagus cunniculus)

for livestock feed. Many forest, farm produce and products, agro-industrial byproducts and animal by-products had been evaluated and found as suitable replacements for some conventional feedstuffs.Rabbits may have the potential of utilizing such unconventional feedstuffs as teak (Tectona grandis) kernel meal. Teak kernel meal has crude protein of $8.75 \%$ from the preliminary proximate analysis carried out on the kernel. This makes it comparable to maize which is a source of energy. It is on this basis that the study was carried out to determine the growth performance and carcass evaluation of rabbits fed teak kernel meal.

\section{Materials and methods}

\section{Experimental location}

This study was carried out at the rabbit section of Ibrahim Badamasi Babangida University Teaching and Research Farm, Lapai, Niger State. Lapai is very close to Minna (State capital), which lies between Latitude $9^{\circ} 31$ and $9^{\circ} 45$, east of the equator (Usman, 2011). The area falls within the Southern Guinea Savannah Vegetation Zone of Nigeria with mean annual rainfall between $1100-1600 \mathrm{~mm}$ and a mean temperature between $21^{\circ} \mathrm{C}$ and $36.5^{\circ} \mathrm{C}$ (Usman, 2011).

Sourcing and processing of feedstuffs Soybean, limestone, wheat offal and bone meal were purchased from Feedtech Limited, Suleja, while maize and salt were purchased from Lapai local market. Teak kernels were sourced for at Cheche village, Lapai Local Government Area of Niger State, Nigeria. They were obtained between January and March, when they were abundant. The calyx layer of the kernel was removed via sievingand rubbing in-between the palms, and the middle layer coupled with the innermost layer were crushed and milled using huller mill to obtain teak kernel meal.
Experimental diets and management of rabbits

Thirty weaned rabbits, aged between $4-5$ weeks, of mixed sexes were purchased from a rabbit farmer in Apata Area of Ibadan in Oyo State.They were randomly allotted into five treatment groups of six rabbits each in a completely randomised design. Each treatment has two replicates of three rabbits each. Five experimental diets were formulated withapproximated crude protein level of $18 \%$. Diet $1\left(\mathrm{~T}_{1}\right)$ served as a control containing every other feedstuff except the test ingredient - teak kernel meal (TKM). Diets 2, 3, 4 and 5 designated as $\mathrm{T}_{2}$, $\mathrm{T}_{3}, \mathrm{~T}_{4}$ and $\mathrm{T}_{5}$ respectively contained TKM at inclusion levels of 5, 10, 15 and $20 \%$ respectively. Table 1 shows the composition (\%) of experimental diets. All diets were supplemented with equal amount of wheat offal, salt, limestone and bone meal. The rabbits were dewormed and appropriate medicationswere administered as at when due. The cages were equipped with feeders and drinkers. Prior to the start of the study, the animals were fed the same diet and were allowed an adjustment period of seven days to enable the animals get used to the cages. Experimental diets and water were provided ad-libitum throughout the experimental period of 12 weeks.

\section{Data collection \\ Determination of proximate and anti- nutritional factors}

Proximate analysis of teak kernel meal was determined according to A.O.A.C. (2000).NFE was calculated by subtracting the sum of crude protein, crude fibre, ether extract, and ash from 100\% dry weight sample (AOAC, 1995). Metabolizable energywas calculated using the procedure of Asibey-Berko and Tayie (1999). Antinutritional factors:flavonoid, phytate, tannin, oxalate and cyanogenic glycoside 
Egbewande, Olorunsanya and Adebanjo

Table 1: Gross composition of experimental diets fed to the rabbits

\begin{tabular}{llllll}
\hline \multirow{2}{*}{ Ingredient (\%) } & \multicolumn{5}{c}{ Teak kernel meal } \\
\cline { 2 - 6 } & $0 \%$ & $5 \%$ & $10 \%$ & $15 \%$ & $20 \%$ \\
\hline Maize & 61.46 & 56.79 & 51.46 & 46.46 & 41,45 \\
Soybean & 24.79 & 24.79 & 24.79 & 24.79 & 24.79 \\
Teak kernel meal & 0.00 & 5.00 & 10.00 & 15.00 & 20.00 \\
Wheat offal & 10.00 & 10.00 & 10.00 & 10.00 & 10.00 \\
Salt & 0.25 & 0.25 & 0.25 & 0.25 & 0.25 \\
Bone meal & 2.00 & 2.00 & 2.00 & 2.00 & 2.00 \\
Limestone & 1.50 & 1.50 & 1.50 & 1.50 & 1.50 \\
Total & 100.00 & 100.00 & 100.00 & 100.00 & 100.00 \\
Calculated (\%) & & & & & \\
Crude protein & 17.94 & 17.96 & 17.93 & 17.91 & 17.91 \\
Crude fibre & 4.27 & 6.89 & 9.49 & 12.1 & 14.71 \\
Ether extract & 3.98 & 3.94 & 4.02 & 4.11 & 4.21 \\
Ash & 2.92 & 3.12 & 3.30 & 3.30 & 3.67 \\
ME (kcal/100g & 332.591 & 344.572 & 334.518 & 368.388 & 379.238 \\
\hline
\end{tabular}

were also determined according to A.O.A.C. (2000).

Determination of performance characteristics of the rabbits

Performance parameters measured from data generated weekly in the feeding trial included feed intake, body weight change, feed conversion ratio and protein efficiency ratio. The following formulae were used for the performance parameters:

Feed intake $=($ Quantity of feed served - left over)g

Feed conversion ratio $=($ Quantity of feed consumed $\div$ weight gain by the rabbits) g

\section{Carcass evaluation}

At the end of the study, four rabbits per treatment were randomly selected, final live weights taken, and then starved overnight by allowing them access to water only. The animals were killed by stunning with a wooden club at the base of the head behind the ears and were then slaughtered by cutting the jugular vein and carotid artery at the level of the atlas vertebra. Proper bleeding was allowed and the carcasses were dressed by removing their pelts and were decapitated at the atlanto-occipital joint (head). The hind feet were cut along the joint between the tibia calcaneus while the fore feet were at carpal region and the tail cut closed to the base. Evisceration was then accomplished by removing the internal organs (heart, liver, kidneys, lung and the full gut), weighed individually, and then expressed as percentage of the carcass weight.

The hot carcass weight was recorded and the fat was collected from fat depots. The carcasses were stored in a freezer pending carcass analysis, during which they were thawed and the chilled carcass weights were recorded. They were further cut into prima cuts, and deboning was manually done according to Awosanya (1989). The fats were collected from three depots in the animal body and weighed. These are: interscapular fat deport (fats on the dorsal side and between the scapulars, extending to neck region and the clavicle bones), inguinal fat deport (fats deposited subcutaneously around the inguinal region prior to evisceration), and perirenal fat depot (fats on the ventral region of the carcass internally surrounding the kidneys 
down to the pelvic region after evisceration). The carcass length was determined using tape rule from the anterior edge of the first rib to anterior edge of aitchbone of the pelvis. Cutting into primal parts was done by first dividing the carcasses into two symmetrical halves as much as possible by splitting the vertebral columns. Each half of the carcass was then divided into shoulder, rib, loin and leg. Shoulder was removed by cutting between $5^{\text {th }}$ and $6^{\text {th }}$ ribs perpendicular to the back line. The rib was thereby separated from the loin by cutting behind the $12^{\text {th }}$ rib following its curvature. Loin was separated from the leg by cutting at the tip of the ilium perpendicular to the chine bone according to Awosanya (1989). Weights of the prima parts were taken and recorded. Two different symmetrical halves of carcasses were selected per treatment to make complete whole carcass. The deboningof the primal cuts were manually done and the lean and bones were weighed separately.

\section{Data analysis}

Data collected on body weight, feed intake, feed conversion ratio and protein efficiency ratio were subjected to analysis of variance (ANOVA) using statistical analysis system package (SAS, 1999).

\section{Results and discussion}

Results from proximate analysis of teak (Tectona grandis) kernel meal (TKM) are presented in Table 2. The TKM was found to be rich in crude fibre (54.9\%), but low in crude protein $(8.75 \%)$ and ash $(5 \%)$. TSM dry matter, ether extract and nitrogen free extract percentages are 92.64, 8.50 and $16.88 \%$ respectively, while ME is 1618.29 $\mathrm{kcal} / \mathrm{kgDM}$. Values for crude protein and ether extract from this study were lower than what were reported by Olorunsanya et al. (2013) for teak seed meal. Thecrude protein and nitrogen free extract values from this study were also lower than those of Ocheja et al. (2011) who reported 10.13 and $68.13 \%$ for teak leaf. Crude fibre value $(54.9 \%)$ obtained from this study is far above what was reported by Olorunsanya et al. (2013) for teak seed meal. The antinutritional factors in teak kernel meal are presented in Table 3. Tannin in TKM did not affect the growth rate and feed intake of the rabbits because of the low value recorded from the analysis. This is contrary to the report of Makkar (2003) that tannin, the most important anti-nutritional factorin legume seeds, decreases the growth rate and feed intake of animals as a result of low palatability and decrease in various enzymatic activities. Other anti-nutrients values determined in this study are very low and as such did not pose any threat to the animals. The results on growth performance of the experimental animals are presented in Table 4. It showed that there were significant $(\mathrm{P}<0.05)$ differences in the feed intake with the highest $(422.55 \mathrm{~g})$ recorded in rabbits fed $10 \%$ TKM. The lowest $(367.67 \mathrm{~g})$ weekly feed intake was recorded in rabbits fed 5\% TKM. The growth performance indices, except feed intake, showed no significant $(\mathrm{P}>0.05)$ differences among the treatment means. The highest final weight $(1635.83 \mathrm{~g})$ was recorded in rabbits fed control diet while the lowest (1411.20g) was recorded for those fed 20\% TKM. This result indicated that the more the level of inclusion of TKM the lower the final weight of the rabbits. Highest weekly feed intake was recorded for rabbits fed control diet while the lowest was the rabbits fed $15 \%$ TKM diet. Feed conversion ratio and protein efficiency ratio were at the best in the control followed by $15 \%$ and $5 \%$ TKM respectively. Final body weights recorded in this study were lower than what were reported by Jiya et al. (2013) who fed graded levels of processed tallow seed meal 


\section{Egbewande, Olorunsanya and Adebanjo}

to rabbits. This parameter is also lower than what were reported by Idowuet al. (2013) who fed weaned rabbits with diets containing bamboo leaf meal.Final body weight and daily weight gainof the rabbits in this study indicated higher values than what were reported by Abduet al. (2011) who fed acacia pod meal-charcoal based diet togrowing rabbits. These, however, were lower than the results of Amaefule et al. (2011) who fed weaned rabbits with diets supplemented with organic acids. Results of the average daily weight gain and average daily feed intake from this study were lower than the reports of Abdu et al. (2012) when they fed Ziziphus mauritiana leaf meal to growing rabbits. However, average daily weight gain in this study is better than the reports of Adeniji et al. (2012) who fed grower rabbits with Gmelina arborea leaf meal. Average feed intake in this study compared favourably with the reports of Orayaga and Goholshak (2014) who fed growing rabbits with different sources of groundnut meals, and results showedlittle disparity in the final weight of the rabbits. The differences in the final weights might be due to the difference in the levels of the test ingredients. The low feed intake recorded in this study may be attributed to the high fat and energy of TKM, which is in accordance with the report of Omole et al. (2007) that rabbits will consume less feed when the energy and or fat content(s) are/is high. This is because animals generally feed to meet their energy requirements.

Table 2: Chemical composition of teak kernel meal

\begin{tabular}{lc}
\hline Parameter (\%) & Composition \\
\hline Dry matter (DM) & 92.64 \\
Moisture & 7.36 \\
Crude protein (CP) & 8.75 \\
Ether extract (EE) & 8.50 \\
Crude fibre (CF) & 54.50 \\
Ash & 5.00 \\
Nitrogen free extract (NFE) & 16.88 \\
ME (kcal/100g) & 560.52 \\
\hline
\end{tabular}

Table 3: Anti-nutritional factors in the teak kernel meal

\begin{tabular}{ll}
\hline Parameters (\%) & Composition \\
\hline & \\
Flavonoid & 3.12 \\
Alkanoids & 0.42 \\
Phytate & 3.65 \\
Tannin & 2.35 \\
Cyanide & 0.32 \\
Oxalate (mg) & 28.60 \\
\hline
\end{tabular}

Table 5 shows the slaughter information and the external offal of the growing rabbit fed the test ingredient. There were no significant $(\mathrm{P}>0.05)$ differences in all the parameters considered. However, rabbit fed control diet had the highest (1738.73g) shrink weight, followed by rabbit on diet 4 (1453.50), while the least (1328.00g) was recorded at treatment 5 . The same trend was noticed in bled weight, hot carcass, chilled 
Graded levels of teak (Tectona grandis) kernel meal on growth performance and carcass characteristics of rabbit (Oryctolagus cunniculus)

Table 4: Performance of weaned rabbits fed teak kernel meal

\begin{tabular}{|c|c|c|c|c|c|c|c|}
\hline \multirow[t]{2}{*}{ Parameter } & \multicolumn{5}{|c|}{ Teak kernel meal } & \multirow[t]{2}{*}{ SEM } & \multirow[t]{2}{*}{ SIG } \\
\hline & $0 \%$ & $5 \%$ & $10 \%$ & $15 \%$ & $20 \%$ & & \\
\hline Initial weight (g) & 370.00 & 420.00 & 400.00 & 362.00 & 358.00 & 5.59 & NS \\
\hline Final weight (g) & 1635.83 & 1448.80 & 1461.40 & 1421.20 & 1411.20 & 96.90 & NS \\
\hline Av. Daily wt. gain (g) & 14.06 & 11.43 & 11.78 & 11.77 & 11.39 & 9.36 & NS \\
\hline Wkly. feed intake (g) & $373.98^{c}$ & $367.67^{d}$ & $422.55^{\mathrm{a}}$ & $412.80^{b}$ & $421.47^{\mathrm{a}}$ & 8.07 & $*$ \\
\hline Daily feed intake (g) & 53.43 & 52.52 & 60.36 & 58.97 & 60.21 & 1.84 & NS \\
\hline Feed to gain ratio & 3.67 & 5.23 & 5.17 & 4.77 & 5.06 & 3.15 & NS \\
\hline Mortality $(\%)$ & 0.00 & 16.67 & 16.67 & 16.67 & 16.67 & & \\
\hline
\end{tabular}

Table 5: Effect of teak kernel meal on slaughter weights and the external offal of the growing rabbits

Parameter

(g)

Teak kernel meal

SEM SIG

\begin{tabular}{|c|c|c|c|c|c|c|c|}
\hline & $0 \%$ & $5 \%$ & $10 \%$ & $15 \%$ & $20 \%$ & & \\
\hline Shrink weight & 1738.73 & 1432.75 & 1390.50 & 1453.50 & 1328.00 & 78.09 & NS \\
\hline Bled weight & 1703.50 & 1397.50 & 1350.25 & 1419.75 & 1277.00 & 78.59 & NS \\
\hline Blood loss & 35.23 & 35.25 & 40.25 & 33.75 & 51.00 & 52.14 & NS \\
\hline Hot carcass & 886.00 & 705.25 & 689.00 & 722.50 & 652.50 & 31.54 & NS \\
\hline \multicolumn{8}{|l|}{ Chilled } \\
\hline carcass & 876.00 & 691.00 & 679.75 & 706.00 & 640.50 & 31.69 & NS \\
\hline Chilled loss & 10.00 & 14.25 & 9.25 & 16.50 & 12.00 & 14.43 & NS \\
\hline Pelt & 183.25 & 116.25 & 127.50 & 123.00 & 122.00 & 131.8 & NS \\
\hline Feet & 38.50 & 38.25 & 36.25 & 43.25 & 38.25 & 36 & NS \\
\hline Tail & 4.50 & 6.50 & 5.00 & 6.00 & 6.00 & 3.87 & NS \\
\hline Head & 166.50 & 137.50 & 137.00 & 152.00 & 136.50 & 343.53 & NS \\
\hline
\end{tabular}

Table 6: Effect of teak kernel meal on visceral organs of grower rabbits

\begin{tabular}{|c|c|c|c|c|c|c|c|}
\hline \multirow[t]{2}{*}{ Parameter $(\%)$} & \multicolumn{5}{|c|}{ Teak kernel meal } & \multirow[t]{2}{*}{ SEM } & \multirow[t]{2}{*}{ SIG } \\
\hline & $0 \%$ & $5 \%$ & $10 \%$ & $15 \%$ & $20 \%$ & & \\
\hline Heart & 0.47 & 0.58 & 0.54 & 0.45 & 0.42 & 0.02 & NS \\
\hline Kidney & 1.04 & 1.61 & 1.47 & 1.43 & 1.29 & 0.13 & NS \\
\hline Liver & 3.89 & 5.03 & 4.39 & 3.92 & 5.23 & 0.69 & NS \\
\hline Lung & 1.56 & 1.79 & 1.74 & 1.48 & 1.53 & 0.26 & NS \\
\hline Gut & 29.47 & 32.92 & 36.29 & 36.23 & 38.31 & 246.35 & NS \\
\hline Perirenal fat & 16.75 & 18.75 & 22.33 & 9.25 & 12.25 & 158.12 & NS \\
\hline Scapular fat & 1.13 & 7.00 & 4.00 & 2.63 & 3.63 & 73.29 & NS \\
\hline Inguinal fat & 15.00 & 15.33 & 19.33 & 11.75 & 6.75 & 11.51 & NS \\
\hline
\end{tabular}

$\mathrm{SEM}=$ Standard Error of Means, NS = not significant 


\section{Egbewande, Olorunsanya and Adebanjo}

carcass and head. Rabbits fed control had the highest (183.25g) pelt followed by treatment $3(127.50 \mathrm{~g})$, while treatment 5 had the least $(122.00 \mathrm{~g})$. Rabbit on treatment 4 recorded the heaviest $(43.25 \mathrm{~g})$ feet followed by treatment $1(38.50 \mathrm{~g})$ and the least $(36.25 \mathrm{~g})$ from treatment 3 . The highest weight $(6.50 \mathrm{~g})$ for tail was recorded in treatment 2 followed by treatments 4 and $5(6.00 \mathrm{~g})$ while the least was in the control.

Table 6 shows the effect of TKM on visceral organs of the experimental rabbits.

Visceral organs showed no significant
( $\mathrm{P}>0.05)$ difference. Rabbits fed 5\% TKM had the highest heart $(0.58 \%)$, kidney $(1.61 \%)$ and lung $(1.79 \%)$, while those fed 20,0 and $15 \%$ had the lowest heart, kidney and lung. Liver at $20 \%$ was at the highest $(5.23 \%)$ while rabbits on control diet had the lowest liver value $(3.89 \%)$. Perirenal and inguinal fats were at the highest (22.33 and $19.33 \%$ respectively) at $10 \%$, while those fed 20\% TKM had the lowest (12.25 and $6.75 \%$ respectively) for the same parameters. Scapular fat was at the lowest $(1.13 \%)$ and highest $(7 \%)$ at 0 and $5 \%$ respectively.

Table 7: Effect of teak kernel meal on carcass cuts and carcass measurements of grower rabbits

\begin{tabular}{|c|c|c|c|c|c|c|c|}
\hline \multirow[t]{2}{*}{ Parameter (\%) } & \multicolumn{5}{|c|}{ Teak kernel meal } & \multirow[t]{2}{*}{ SEM } & \multirow[t]{2}{*}{ SIG } \\
\hline & $0 \%$ & $5 \%$ & $10 \%$ & $15 \%$ & $20 \%$ & & \\
\hline Shoulder & 13.02 & 13.21 & 13.59 & 12.48 & 12.89 & 0.90 & NS \\
\hline Rib & 6.38 & 6.91 & 6.79 & 6.15 & 5.89 & 0.37 & NS \\
\hline Loin & $11.86^{\mathrm{a}}$ & $9.97^{\mathrm{b}}$ & $10.11^{\mathrm{ab}}$ & $11.46^{\mathrm{a}}$ & $11.43^{\mathrm{a}}$ & 0.93 & $*$ \\
\hline Leg & 20.09 & 19.74 & 19.31 & 19.34 & 20.00 & 0.74 & NS \\
\hline Thigh width (inch & 3.23 & 2.98 & 2.98 & 3.10 & 2.95 & 1.00 & NS \\
\hline Carcass length (inch) & 9.65 & 9.23 & 9.10 & 9.28 & 8.93 & 0.25 & NS \\
\hline \multicolumn{8}{|l|}{ Lean:bone } \\
\hline Shoulder & 06:01 & 07:01 & 06:01 & 05:01 & 06:01 & & \\
\hline Rib & 05:01 & 06:01 & 05:01 & 04:01 & 05:01 & & \\
\hline Loin & 05:01 & 04:01 & 04:01 & 03:01 & 05:01 & & \\
\hline Leg & 02:01 & 03:01 & 03:01 & 03:01 & 03:01 & & \\
\hline
\end{tabular}

Effect of teak kernel meal on carcass cuts and carcass measurements of grower rabbits is presented in Table 7. There were no significant $(\mathrm{P}>0.05)$ difference in all the parameters measured except in loin where the means were significantly $(\mathrm{P}<0.05)$ different. Rabbits fed control diet exhibited the highest values in all the parameters except in shoulder and rib. Values of loin obtained from this study were lower than the reports of Abu and Tanimowo (2012). The values were higher than the report of Ahmaefule et al. (2011) for shoulder and loin. The lean to bone ratio (Table 7) was at the best for rabbits fed 5\% TSM diet for both rib and shoulder. Rabbits fed experimental diets were better than those fed control diet as with respect to lean to bone ratio of the leg.

\section{Conclusion}

Results from this study suggested that teak kernel meal can be incorporated in the diets of rabbits for maximum performance. It is non-toxic because it showed no deleterious effects on the animals. Also, inclusion of teak kernel meal in the diets of rabbits produced better economic benefits than when using soybean meal as source of plant protein. It is concluded that teak kernel meal should be fed up to $20 \%$ level of inclusion. 
References

Abdu, S. B., Bako, H., Hassan, M. R., Jokthan, G. E., Yashim, S. M., Adamu, H. Y. and Abdulrashid, M. 2011. Effect of charcoal inclusion on the performance of growing rabbits fed Acacia (Acacia nilotica) pod meal based diet. Nigerian J.Anim. Sci. 13:133 141.

Abdu, S. B., Hassan, M. R., Adamu, H. Y., Yashim, S. M., Abdulrashid, M., Duru, S. and Jokthan, G. E. 2012. Costs benefit analysis of level of Ziziphus (Ziziphus mauritiana) leaf meal inclusion in the diet of growing rabbits. Nigerian Journal of Animal Production, 39(II): 90-95.

Abu, O. A. and Tanimowo, D. A. 2012. Effect of $\beta$-mannanase supplementation and feed presentation on cassava characteristics and macro-mineral digestibility of growing rabbits fed palm kernel based diets. Nigerian Journal of Animal Production, 39(II): 83-89.

Adeniji, A. A., Gana, E., Olafadehan, O. A., Chibougwu, I. C. and Saria, M. I. 2012. Performance of grower rabbits fed Gmelina arborea leaf meal. Nigerian Journal of Animal Production, 39(II): 66-70.

Ahmaefule, K. U., Mbagwu, I. I. and Inyang, N. E. 2011. Performance, nutrient utilization and intestinal environment of weaned rabbits fed diets supplemented with organic acids in the humid tropics. Nigerian J. Anim. Sci. 13: 69-79.

Akinusi, F. A. O., Bamgbose, M., Sogunle, O. M., Oso, A. O. and Afolabi, F. O. 2007.Comparative effect of different animal protein concentrates on the carcass quality of rabbits. Proceeding of the $32^{\text {nd }}$ Annual Conference of the Nigerian Society for Animal Production, March, 18-21, Calabar, Nigeria.

A.O.A.C. 2000. Official method of analysis of the Association of Official Analytical Chemistry, $17^{\text {th }}$ edition, W a s h i n g t o n, D. C.

Asibey-Berko, E. and Taiye, F. A. K. 1999. Proximate analysis of some underutilized Ghanaian vegetables. GhanaJ.Sci. 39: 91-92.

Awosanya, B. 1989. Carcass characteristics of rabbits fed maize replaced with palm oil sludge. Ph.D. Thesis, Department of Animal Science, University of Ibadan, Oyo State, Nigeria

Egbo, M. L. Doma, U. D. and Lacdaks, A. B. 2001. Characteristics of small scale rabbit production and management in Bauchi metropolis. Proceedings of the $26^{\text {th }}$ Annual Conference of Nigerian Society for Animal Production (NSAP), 18-21 March, 2001, ABU Zaria, Pp. $\begin{array}{lllllll}1 & 6 & 0 & - & 1 & 6 & 2\end{array}$

Idowu, O. M. O., Oso, A. O., Adeyemi, O. A., Osho, S. O., Idowu, O. P. A. and Ijaya, A. T. 2013. Growth response and apparent nutrient digestibility of weaner rabbits fed with diets containing bamboo leaf meal. Nigerian Journal of Animal Production, 40(2): 52-58.

Jiya, E. Z., Ijaya, A. T., Olorunsanya, A. O. and Ayanwale, B. A. 2013. Performance of rabbits fed diets containing graded levels of processed tallow (Detarium microcarpum) seed meal. Nigerian Journal of Animal Production, 
40(2): 59-70.

Madubuike, F. N. and Obidimma, V. N. 2009. Brewer's dried grain as energy source on external and internal egg qualities of laying hens. Proc. $34^{\text {th }}$ Ann. Conf. Nig. Soc. Anim. Prod., Uyo. Pp. 362 $-365$

Makkar, H. P. S. 2003. Effects of fats and tannins on ruminant animals, adaptation to tannin and strategies to overcome detrimental effects of feeding tannin rich feeds. Small ruminants research, 49:241-256.

Mariu, J. I., Njoka-Njiri, E. N., Tuitoek, J. N. and Nanua, J. N. 2002. Evaluation of sorghum (Sorghum bicolor) as replacement of maize in the diet of growing rabbit (Oryctolagus cunniculus). Asian Australisian.Journal of Animal Science, 15: 565-569.

Ocheja, J. O., Ebiloma, S. O., Ukwuleno, S. O., Ogunche, H. G. E., Lalabe, B. C. and Akuboh, C. A. 2011. Performance and haematological parameters of grower rabbits fed with some supplemented with a mixture of Bambara nut waste and rice offal. PAT, Publication of Nasarawa State University Journal. 7(2): 37-47.

Olorede, B.R. and Longe, O.G. 1999. Growth, nutrient retention, haematology and serum chemistry of pullet chicks fed sheabutter cake in the humid tropics. Arch. Zootec., 49: 441-444.
Olorunsanya, A. O., Egbewande, O. O., Ibrahim, H., Musa, A. A., Boku, A. L., Yusuf, M. K. and Garba, E. 2013. Carcass characteristics of broiler chickens fed graded levels of teak (Tectonagrandis Linn.) seed meal. Proceeding of $38^{\text {th }}$ Conference of Nigerian Society of Animal Production, March, 2013. Rivers State University of Science and Technology, Port Harcourt, Nigeria, 778-780.

Orayaga, K. T. and Goholshak, P. M. 2014. Comparative evaluation of effects of different sources of groundnut meals on digestibility, growth performance and economics of production of growing rabbits.Nigerian Journal of Animal Production, 41(1): 272283.

SAS 1999. SAS/STAT User's Guide.Version 8 for Windows.SAS Institute, Cary, North Carolina, USA.

Usman, H. I. 2011. Effect of time of intercropping soybean on weed suppression and performance of upland rice in southern guinea savannah of Nigeria. Ph.D. Thesis, Department of Crop Production, Federal University of Technology, Minna,pp. 24.

Received: 25 ${ }^{\text {th }}$ August, 2016 Accepted: 12 $2^{\text {th }}$ March, 2017 